\title{
Simulated Happiness in the World
}

\author{
Eda CAYIR* \\ Istanbul Aydin University English Language and Literature Department, Istanbul \\ *Corresponding Author: Eda CAYIR, Istanbul Aydin University English Language and Literature
} Department, Istanbul

\begin{abstract}
In Huxley's Brave New World and Zamyatin's We - both of which uncoincidentally came out of the 1900s - machine-like people, or more precisely, people-like creatures come to exist in an 'unquestionable' world. That unquestionnability has such a huge dominance over 'people being, or in other words, claiming that they are happy' that one can frequently encounter the concept of 'happiness' throughout the two novels. The common understanding of both novels is a world based on a functional mechanism, which means 'coded, incubated, conditioned' people such as D-503, O, R-13, Alfa, Beta etc. Therefore, the argument will aim to lay bare, through the settings and the discourses, the latent content rather than the visible one, and at what level citizens of the two depicted societies are happy.
\end{abstract}

Keywords: happiness, eudaimonism, simulation, codification, conditioning

In a world seized by technology, mentioning 'a real world' is out of the question. Hence, this argument gives birth a revolutionary question: 'If it were not a real world, what would it be?' In response to the question, could 'simulation' under the name of 'standartised infinite happiness' answer the question?

According to Aristotle, 'eudaimonia ${ }^{1}$, defines in which way people reach happiness and what the nature of that happiness is. Aristotle asserts that the road towards happiness is based on reason, but not to the extent of ignoring emotion; One must choose the proper route by means of reason and must distinguish what happiness is through emotion to live life at its best. As it is seen, the Aristotelian definition of happiness encapsulates both reason and feeling. In doing so, under the light of "virtue and vice", he asserts that binary opposition is the only way to comprehend the distinction between animals and human beings.

In accordance with this, in both novels the readers encounter people-like creatures who cannot use their rational (cognitive) side, or can too slightly. However, they stress their happiness as being diametrically opposed to Aristotle's eudaimonia. Brave New World, as being different from We, opens with a description of the process of producing babies, including fertilization, in 'the Central London Hatchery Conditioning Centre". At this point, bokanovskification - the most effective operationshows itself. The Director describes it with the following words "bukanovskification consists of a series of arrests of development..." (Huxley,7). With the aim of "stability'a 'world conditioner "designs everything for the sake of "COMMUNITY, IDENTITY, STABILITY" (The planetary motto). This triplet is described as "Grand words". In such a designed (simulated) world, after being exposed to a number of operational phases such as incubation, codification, injection and so on..., how would it be possible to mention the archetypal concept of world?

As the text mentions, in a simulated world a high- power mechanism exists and shapes people in two ways; while one is to divest them of feelings and even of organic instincts, the other is to expose them to many operations. After the process of conditioning, "hypnopædia"'-a psychological weaponcomes into play, as the next step, to complete simulation. It is used in moral education. The Director's definition of hypnopædia sheds light on to what extent they play a conditioner (simulator) role:

Moral education which ought never, in any circumstances, to be rational before the child can speak. But wordless conditioning is crude and wholesale, cannot bring home the finer

\footnotetext{
${ }^{1}$ Happiness in Greek
} 
distinctions, cannot in calculate the more complex courses of behaviour. For that there must be words but words without 'reason'. In brief, hypnopædia. (Huxley, 21)

Instinctively hatred of books and flowers caused by"The World State" is a clear clue to evaluate the system's aim: to estrange them from their own nature. "The greatest moralizing and socializing force of all time" (Huxley, 27). So, one can observe how extensively the conditioner surrounds 'people' and how meticulously chosen the conditioning systems are.

Another noteworthy point on conditioning is the "Great Operation" in We. After detecting that some simulated people are starting to have fantasies, and moreover to feel cognitive presence or to be more precise, when the humanistic parts try to come to life, the Great Operation is applied to everyone without exception because the system does not have any toleration for the slightest possibility of its authority being shaken ("The One State").These possibilities are expressed as an illness:"It's incomprehensible. The only explanation: my former illness (the soul)"as D-503 says (Zamyatin, 2, 40th record) . The operation's only aim is to get rid of "the enemies of happiness"" Before the "Great Operation", the readers have already faced the One State's "self-definition", carrying traces of a threat; " "If they do not understand that we bring them mathematically infallible happiness, it is our duty to force them to be happy but before arms , we try the word "...duty-bound" works on the beauty and greatness of the One State" (Zamyatin, 2, 1st record). This simulation- the One State- is illustrated as "the great, divine, precise, wise world -the wisest" one (Zamyatin, 2,1st record).Here, inevitably one can understand that "the wisest" overlaps completely with "stability" as the simulated worlds" primary goal.

Through rapid technological development, a world where unawareness and a kind of hedonic perception, at least to a certain extent, are built. In accordance with the former, each person is satisfied with his position. For the latter, that understanding aims to maximize pleasure and minimize pain; which issupported, in both novels, by dint of'soma" (a sort of narcotic) and sex. The Director says, referring to the conditioning "that is the secret of happiness and virtue- liking what you've got to do. All conditioning aims at that: making people like their unescapable social destiny" (Huxley, 12).

As to the notion of happiness mentioned, their happiness stems from immediate pleasures (sex, soma). The only thing to feel free is having sex for both novels. Within this scope, hedonism may be a truer definer of both happiness understandings rather than eudonism. Just in the course of sexual intercourses, by means of scheduled "pink cards" on which are written with whom they will have sex, they take pleasure and feel 'happy'.'Regularly' they are allowed to have it. It does make them, in a sense, feel as it were free. That is why, that hedonic side is intentionally left in the world with respect to maintain the continuity of the "stability". Because people, in a simulated world, do not have any ability to distinguish whether they are indeed free or not. Simulation complicates this distinction.

In his Simulacra and Simulation Jean Baudrillard, as a defogger, defines the concept of simulation:

...to dissimulate is to feign not to have what one has. To simulate is to feign to have what one hasn't. One implies a presence, the other an absence. But the matter is more complicated, since to simulate is not simply to feign: Someone who feigns an illness can simply goto bed and pretend he is ill. Someone who simulates an illness produces in himself same of the symptoms. Thus, feigning or dissimulating leaves the reality principle intact: the difference is always clear only masked; whereas simulation threatens the difference between "true" and "false", between "real" and "imaginary". So, the simulator produces "true symptoms" (Baudrillard, 2).

Certainly, this incomprehensibility is valid for each notion and emotion in both novels.Then, it should not be expected that the simulated people notice the distinction between a 'real human' and 'simulated one', between 'happy' and 'sad', between 'free' and 'dependent' individuals.

Having stated the previous assumptions, Gandhi's words on happiness render the argument's core clearer: 'Happiness is when what you think, what you say, and what you do are in harmony'. $\mathrm{He}$ highlights that freedom and happiness progress hand in hand. If the term "free" cannot be used for any of the characters in either novel, how are they supposed to be happy? Surely, there is a happiness but inorganic. Then, the world simulated by technology simulates not only the cognitive parts but also the organic parts of human beings. At the end, the readers face a picture, and when the whole picture is 
seen, indisputably the simulation discloses itself. The people who are created inorganically, or in other words, those who are adapted to the simulation meet with the readers. People purified from all unnecessary organic parts keep claiming that they are happy, and on this simulative road, by treading on sufficiently untreated ones, continue their journeys happily.

\section{REFERENCES}

[1] Baudrillard, Jean, and Sheila Faria. Glaser. Simulacra and simulation. Univ. of Michigan Press, 2014

[2] Huxley, Aldous.Brave New World .London: Vintage, 1994

[3] Zamyatin, Yevgeny. WeTrans. by Hugh Aplin, United Kingdom: Alma Books, 2009.

\section{AUTHOR'S BIOGRAPHY}

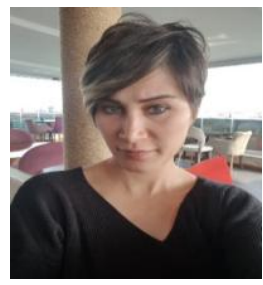

EDA CAYIR, I am 30 and married. I am from Istanbul. I have two handsome kids always motivating me to progress in the field of literature. Literally, I am a multidisciplinary person due to getting my bachelor degree from French Language and Literature. For Mla, I prefered progressing via English language and literature to broaden my literary vision. Beyond being a student, my steps are towards being an academicien in the department of Comparative Literature.

Citation: Eda CAYIR. Simulated Happiness in the World. "International Journal on Studies in English Language and Literature (IJSELL), vol 7, no. 7, 2019, pp. 1-3. doi: http://dx.doi.org/ 10.20431/2347-3134. 0707001 .

Copyright: (0) 2019 Authors. This is an open-access article distributed under the terms of the Creative Commons Attribution License, which permits unrestricted use, distribution, and reproduction in any medium, provided the original author and source are credited. 